\title{
UNIT SIMULATION
}

\author{
Reconnect with your past.
}

\section{BY COY ST CLAIR}

$\mathrm{T}$ The street was empty for as far as Jane could see, and she was resigned to another night without a customer. This would be three nights in a row. Yuri would not be happy. Jane pulled her coat closer against the evening chill and began walking.

By the time she reached the end of her territory, three cars had passed without slowing down, even though she had looked hopefully at each one. It was insulting, really. She was a professional, after all. She may have been dressed in normal clothes, but there was no mistaking what she was, especially in this part of town. As she turned to make a slow walk down to the other end of her territory, a sedan slowed by the corner. She approached confidently as the passenger window rolled down.

"Looking for a good time, honey?" Jane said, leaning down to look inside the car. The man was not unattractive, with dark hair and nervous blue eyes. He nodded apprehensively. Jane smiled her warmest smile. She prided herself on her ability to reassure the customer, to make them feel comfortable and safe. The real trick of the trade, she knew, was to understand that safety and comfort were what they were really after.

"Do you ... you know, do the whole deal?" the man said, raising his eyebrows.

"No, honey. If that's what you're after you need to go down a few blocks. This is Unit Simulation only," she said, masking the disappointment.

"No, no," he said, shaking his head quickly, "that's what I want. Just the Simulation."

She smiled again. "Sure thing, darling. Just head around the corner. There's a parking structure there. Just park up and meet me

\section{$\rightarrow$ NATURE.COM}

Follow Futures:

3 @NatureFutures

f go.nature.com/mtoodm at the alley around the back."

He nodded again and pulled away.

Jane walked to the back of the building and waited. A few moments later, the man appeared from the structure, furtively glancing around to see if anyone was watching. He was a young professional type, dressed in a dark suit. Jane smiled a winsome smile.

"Don't worry, darling. Nobody comes around here. We're safe," she said. "My fee is one hundred for two hours." She paused with an expectant look for his assent. The man nodded. "Good. This way." Jane took the young man's hand and led him to a stairwell.

Upstairs they entered the studio. There was a couch with matching rug, a fireplace that gently crackled, books on a coffee table - all the little details of a family home from a bygone era, down to the children's toys that were casually strewn about.

"Just take off your coat and sit down," Jane said, indicating the couch. "I'll be right back."

The man complied and sat silently as Jane left the room. In moments she returned, wearing pyjama bottoms and a cotton robe. Two children held her hands as she approached the man. They were Synthetics, but if you didn't look too closely it might not be obvious. Jane knew that her customers didn't come here to examine things closely. They came to experience something that maybe their genes still remembered, and those types weren't interested in picking apart the details.

The man smiled hesitantly and the children smiled back. They hugged his neck and giggled. When they released him and went to play quietly on the rug with their toys, Jane sat on the couch beside the man. She placed a gentle arm around him and drifted into thought as they placidly watched the 'children' play, just as she always did.

There were advantages to the breeding programme, to be sure. Disease and deformity had nearly been eradicated, people were more intelligent, and the human race had finally begun to live in harmony with the planet, instead of at odds with it. But the price, Jane thought, was steep. Children, created and raised by the authorities, were perfect in every way, and perfectly sterile, just like Jane and her client. It had been generations since a true family had existed. Somewhere deep down, Jane knew, people felt that something was missing. The population was stable, meticulously regulated, but people could feel the absence of something lost.

Jane was proud. Even after Family Unit Simulation had been outlawed as a 'disturbance of moral judgment and psychological well-being', Jane had found a way to continue her trade. She knew what they really wanted, and she gave it to them, if only for two hours at a time.

The man looked at Jane with wet eyes and she pulled his head to her shoulder.

"There, there, darling. Everything is all right. You're home now."

Coy St Clair is a biologist and is presently putting the finishing touches on his first novel, The Exile of William Bend. 